\title{
Assessment of institutional conditions of fiscal decentralization in Ukraine
}

\section{Inna Shkolnyk}

Dr., Professor, Head of Department of Finance, Banking and Insurance, Sumy State University, Ukraine

\section{Tetyana Melnyk}

Ph.D., Manager Data Systems and Fiscal Analysis, Revenue Estimating Division, Texas Comptroller of Public Accounts, USA

\section{Borys Mershchii}

Ph.D. Student, Department of Finance, Banking and Insurance, Institute for Business Technologies "Ukrainian Academy of Banking", Sumy State University, Ukraine

\begin{abstract}
A successful reform of financial decentralization in Ukraine requires compliance with a number of institutional conditions that will allow them to achieve their goals efficiently and without resource losses. The purpose of reforming the existing system of local self-government is to increase the degree of citizens needs satisfaction. The reform of financial decentralization is intended to transfer the relevant financial resources to the level of territorial communities in order to satisfy the interests of the community. But for this purpose, it is necessary to create a number of institutional conditions that will organize relations between all stakeholders.
\end{abstract}

An analysis of literary sources confirmed the hypothesis that the relationship between the state and society is determined by a set of institutional conditions that collectively determine the functioning of the economic system. The literary review pointed to the need for a comprehensive perception of institutional conditions as an environment, taking into account territorial bases, legal aspects, financial and economic relations, interpersonal interaction. It was found that institutionalization is the basis for any social changes in society, in particular for a large-scale reform of local self-government - financial decentralization.

The methodical tools were methods of index analysis, which allowed to carry out an equal comparison of heterogeneous institutions according to the institutional conditions of the research objects. The period of observation of the key indicators of public administration was the decade from 2006 to 2016. The aggregate index of institutional conditions for financial decentralization was created in 2012-2016. The subjects of the study were selected European countries with experience in implementing the reform of financial decentralization. Particular attention is paid to the analysis of the corruption component of the institutional environment, since it poses a threat to reform. Some aspects of economic freedom, in particular, the tax burden index, which characterizes the degree of fiscal pressure in the country and the index of state expenditures, are investigated.

The next stage was the construction of an index of institutional conditions of financial decentralization. At the first stage, a baseline of institutional conditions was formed, which included the following: voice and accountability; political stability and lack of violence; the effectiveness of public administration; quality of state regulation; compliance with legislation; control of corruption; tax burden; characteristic of the volume of public expenditures. At the second stage, the absolute normalization of the selected indicators for the period of 20122016 years was carried out. The final stage involves an additive convolution of normalized indicators and obtaining an effective indicator. As a result of the study, it was clarified that a number of institutional environment issues should be addressed in order to carry out an effective reform of financial decentralization. Ukraine should concentrate on solving the problems of political stability, improving the efficiency of public administration, preventing and combating corruption, adhering to legislative norms, and so on. The obtained results of the research should become the benchmark for successful financial decentralization. It is necessary to rely on the experience of more successful European partners, the advantages of which were noted in the process of comparative analysis.

Keywords: efficiency of government institutions, index of institutional conditions of financial decentralization, indices of public administration, institutional conditions, institutionalization, integral indicator, corruption, financial decentralization.

JEL Classification: H70, H60, H40, H20, C43.

(C) The Authors, 2018. This article is published with open access at Sumy State University. 


\section{Introduction}

The process of democratic development of society and its social institutions is constantly, because the ideal of effectively functioning state administration is not achievable. The reason for the problems in the area of local self-government is the lack of a clear and developed management mechanism. Fiscal reform is intended to create conditions of maximum satisfaction of the needs of citizens by transferring the relevant rights and material resources at the level of local communities. In countries with developed democracy, reforming key spheres of public life begins with the construction of an institutional basis. Usually, a basis is understood as the creation of both a system of conditions and the construction of a mechanism for the interaction of subjects. But if we combine the institutional concept with the basics of local self-government, then there are a number of conditions that influence the effectiveness of any reform, in particular, financial decen tralization. The task of scientific research is to improve methodological approaches to assessing the institutional conditions of financial decentralization.

\section{Literature review}

The development of the institutional management concept has begun since the study of the evolution of the social system (Andriyash, 2014). Fundamentals of the institutional approach were developed by T. Veblen, W. Mitchell, J. Commons, D. North, JM Hodgson. All relations between society and the economy are determined by a set of institutional conditions that determine the way the economic system functions. The institution is usually understood as an institution, regarded as a key element of the social structure, is a historical form of organization and regulation of public life by streamlining relations between people in the process of their interaction (Andriyash, 2014). Given the fact that management science is a comprehensive knowledge of the industry, which includes large multidisciplinary body of knowledge, there are other interpretations Institute category. So, for example, in jurisprudence (Inshakov, 2005) the institute is considered a certain branch of legal norms regulating relations in a certain area (Inshakov, 2005). In political science, the institute is considered a form of organization of power and a means of streamlining social relations. The Institute is an important structural element of the political system (Kuhta et al., 2003), which ensures the stable and long-term functioning of the political organization of the social (Kuhta, Romanyuk, Staretska, 2003). Sociological science (Andriyash, 2014) treats the concept of the institute as a certain type of stable regulation of the social ties and organizational forms of social regulation of the subjects of behavior (Andriyash, 2014). In the approaches of psychological science (Osipova, 2003) the concept of social institutions as an organized form of activity in relation to the reproduction of sustainable patterns of behavior, traditions, and customs passed from generation to generation is considered. We will consider the concept of institutional conditions as a certain environment of legal aspects, territorial bases, subject interaction, financial and economic relations, that is, we will carry out a comprehensive study. The issue of institutionalism in foreign scientific schools is also being investigated in diverse areas. In particular, Swenden W. (2017) examined the institutional aspects of governance in India and Pakistan. Vitman K. (2018) focuses on the study of institutionalism, creating an enabling innovative, technological and other conditions for the growth potential of the economic system (Dudchenko, Vitman, 2018). Also investigated the issue of institutional changes and their impact on key economic, political and social processes. Bathelt H., Glueckler J. (2014) proposed a concept vzamozv'yazku between institutional and economic changes in terms of economic geography. Kingston C., Caballero G. worked out theoretical approaches to the conceptualization of institutional changes in the economy. Campbell J. (2004) investigates the mechanisms of institutional changes, examines the problems of institutional analysis, examines the influence of individual institutional factors in solving actual problems. Aoki M. (2007) focuses on the process of historical change of institutions in the economy, considers the institute as a mechanism of social interaction.

Thomsen J. (2008) considers the local economic development within the concept of in-stytutsionalizaiyi, evaluate ways to improve the conditions of institutional development within development planning in transition countries. He investigates the concept of institutional change, assessing the practical applicability of institutional policies in public practice. Gooneratne T N., Hoque Z. (2016) made a contribution to the system of institutional methods of management and management control. Soukopova, J., Bakos, E., Zelenakova, P. (2017) conducted research on the institutional aspects of the interaction of municipalities among themselves, assessed the effectiveness of cooperation in the sector of local self-government. The issues of institutionalism in both public administration and local self-government and the economy as a whole are engaged in a sufficient number of scientific schools, indicating the relevance of the chosen research topic. 
In the scientific literature, the process of institutionalization is sometimes seen as a kind of synonym for democratization. However, a more precise approach is still the understanding of institutionalization, as the normative-legal regulation of public authorities. Zelenko G (2010) believes that the institutionalization of the procedure for determining and formalizing the organizational and legal structures of public authorities to ensure public needs. Cushinskiy O. (2002) expands the limits of institutionalization to the process of formation, liquidation, reorganization of the institutions of the authorities. In spite of the relatively theoretical concept of institutionalization, Lazor O. (2009) treats it as a process of developing local and regional democracy. That is, institutionalization is in fact the basis for any social changes, including to implement the reform of financial decentralization.

\section{Research results}

Current progress towards the development of the methodology of comparative quantitative assessment of the quality of functioning of local government institutions provides opportunities for studying and comparing the preconditions for certain processes, in particular, our assessment is intended to assess the institutional conditions for financial decentralization.

Today, there are a number of regularly updated international ratings and indices that reflect those or other investigated aspects in a national context. One of the most extensive studies of institutional moments in the functioning of public administration bodies is the development of the World Bank (World Bank). Worldwide Governance Indicators include 6 key aspects of government governance: voice and accountability; political stability and lack of violence; the effectiveness of public administration; quality of state regulation; compliance with legislation; control of corruption. The first World Bank studies were launched in 1996 and are ongoing to date. Today, the quality of public administration is estimated more than in 200 countries based on almost 40 sources of data published by various research institutes, think tanks, international organizations (The Worldwide Governance Introduction (WGI) project.).

We will provide a more detailed description of each component of the Public Administration Index for understanding the importance of each of them as prerequisites for financial decentralization, as shown in Table 1.

Table 1. Analysis of components of the state governance index (The Worldwide Governance Introduction)

\begin{tabular}{|l|l|}
\hline \multicolumn{1}{|c|}{ Index } & \multicolumn{1}{c|}{ Characteristic } \\
\hline Voice and Accountability & $\begin{array}{l}\text { Includes indicators that characterize the impact of civil society on the choice of state } \\
\text { administration. It also includes freedom of expression and media independence. }\end{array}$ \\
\hline $\begin{array}{l}\text { Political Stability and Absence of } \\
\text { Violence }\end{array}$ & Displays the probability of political instability or public pressure for political reasons. \\
\hline Government Effectiveness & $\begin{array}{l}\text { Assesses the performance of public authorities (local governments nd) degree of } \\
\text { independence from political pressures, the quality of the selected state rate and degree of } \\
\text { its actual implementation. }\end{array}$ \\
\hline Regulatory Quality & $\begin{array}{l}\text { Displays perception ability of public authorities to shape and implement life provisions } \\
\text { that promote private sector development. }\end{array}$ \\
\hline Rule of Law & $\begin{array}{l}\text { Measures the level of perception of laws by all members of society, their fulfillment. } \\
\text { Includes indicators of population attitudes towards different types of crime, effectiveness } \\
\text { and predictability of the legislative system. }\end{array}$ \\
\hline Control of Corruption & $\begin{array}{l}\text { Displays the extent to which state power is used to obtain personal gain bypassing existing } \\
\text { legal provisions. }\end{array}$ \\
\hline
\end{tabular}

We will compare the values of the indexes of public administration for 2010-2016 among European countries with experience of decentralization reform. We note that the pain of six European countries in one way or another have gone through decentralization. There are undeniably examples of centuries of experience, such as Germany, which, from the times of the Middle Ages, used various models of decentralization: from the bottom up (administrative units required new powers) and from the bottom up (the state gave the right to exercise certain powers at the level of administrative units for a certain reward). One of the typical examples of a decentralized unitary state can be the Netherlands, where the powers and relevant financial resources are divided into 3 levels: the state, the province and the municipality. Serbia also has some experience in implementing the reform of financial decentralization, which has implemented the "Strategy for Public Administration Reform in the Republic of Serbia" since 2004. The immediate neighboring countries of Ukraine also carry out reforms in the direction of decentralization. In particular, in the Republic of Moldova, a "Strategy for the reform of central public administration" was developed and implemented. A special role in creating the Ukrainian model of reform was drawn to the Polish experience, which can be called a significant success, considering the relatively equal starting positions of the countries after the 90 years. The 
selected group of countries was taken as close to Ukraine as well as more advanced for a wider range of comparisons and identification of ways to improve the institutional conditions for conducting a reform of financial decentralization. According to the research methodology, each of the six government governance indexes is evaluated as a result on a scale from -2.5 to +2.5 , where higher values indicate the best practice of implementing a certain component of public administration.

Table 2. Indices of European governance for 2016 (The Worldwide Governance Introduction)

\begin{tabular}{|l|c|c|c|c|c|c|}
\hline \multicolumn{1}{|c|}{ Country } & $\begin{array}{c}\text { Voice and } \\
\text { Accounta- } \\
\text { bility }\end{array}$ & $\begin{array}{c}\text { Political Stability } \\
\text { and No Violence }\end{array}$ & $\begin{array}{c}\text { Effectiveness of } \\
\text { Public Admin- } \\
\text { istration Gov- } \\
\text { ernance }\end{array}$ & $\begin{array}{c}\text { Quality Regula- } \\
\text { tory Compli- } \\
\text { ance }\end{array}$ & $\begin{array}{c}\text { Compliance } \\
\text { with Legis- } \\
\text { lation }\end{array}$ & $\begin{array}{c}\text { Corruption } \\
\text { Control }\end{array}$ \\
\hline Czech Republic & 1.0 & 1.0 & 1.1 & 1.0 & 1.1 & 0.5 \\
\hline France & 1.1 & -0.1 & 1.4 & 1.1 & 1.4 & 1.4 \\
\hline Germany & 1.3 & 0.8 & 1.7 & 1.8 & 1.6 & 1.8 \\
\hline Italy & 1.0 & 0.4 & 0.5 & 0.7 & 0.3 & 0.0 \\
\hline Moldova & 0.0 & -0.3 & -0.6 & -0.1 & -0.5 & -1.0 \\
\hline Netherlands & 1.5 & 0.9 & 1.8 & 2.0 & 1.9 & 2.0 \\
\hline Poland & 0.8 & 0.5 & 0.7 & 1.0 & 0.7 & 0.7 \\
\hline Serbia & 0.2 & 0.0 & 0.1 & 0.1 & -0.1 & -0.3 \\
\hline Switzerland & 1.5 & 1.3 & 2.0 & 1.9 & 1.9 & 2.1 \\
\hline Ukraine & 0.0 & -1.9 & -0.6 & -0.4 & -0.8 & -0.8 \\
\hline
\end{tabular}

The results of the analysis indicate that among the selected list of countries with experience of implementation of the reform of financial decentralization, Ukraine is in the lowest positions with all the indices of public administration. In particular, according to the indicator of the right to vote and accountability, Ukraine together with Moldova scored 0.0 points, while the Netherlands and Switzerland became the leader with an estimated 1.5. It should be noted that among more than 200 countries in the world, the Netherlands and Switzerland are among the leaders in this criterion. At the same time, as Ukraine is somewhere in the middle of the world ranking. This indicates a significant lag in the creation of institutional conditions for reform, in particular, among the general problems of Ukrainian realities, the low effectiveness of state authorities in the direction of reforms, lack of accountability of executive authorities, non-compliance with civil rights, low level of trust to the existing authorities are highlighted.

The results of the index of political stability and lack of violence indicate that Ukraine was the lowest in comparison with other selected countries according to this criterion. Among the institutional problems in Ukraine one can distinguish political persecution, a military conflict within the territory. The estimates obtained are logical, since there are no such problems in Western European countries. Switzerland $(1,3)$ and the Netherlands $(0,9)$ are again leaders of the group. The efficiency index of public administration already has a lesser degree of differentiation with leading countries than the previously investigated index of political stability and lack of violence. Let's note that the result of Ukraine is -0.6 , which is 2.6 points less than the leader of the group - Switzerland.

Similarly, the low result was demonstrated by Moldova (-0.6). Attention should be paid to the following institutional conditions for improving the efficiency of public administration: excessive bureaucracy, the efficiency of the use of resources by state authorities, population satisfaction with the level of infrastructure development (transport system, road system, education system), the efficiency of mobilizing the revenues of the state and local budgets, the dependence of the executive authorities on political interference, the weak degree of adaptation of the state economic policy to changes in the economic situation. The next researched index was the quality of state regulation. The nearest Ukraine (-0.4) was closer to Moldova (-0.1) and Serbia (0.1). In order to create the best institutional conditions for financial decentralization, Ukraine has to solve the following problems: effective regulation of competition in the market sector, elimination of practices of underarmor competition, the fight against discriminatory tariffs, the resolution of tax issues in a debatable way, the quality of compliance with state norms, a low degree of investment and financial freedom, creating a business environment. The results of the assessment of the compliance index indicate that Ukraine has significant problems in this area, since the score -0.8 points is significantly lower than the countries that have succeeded in financial decentralization: Czech Republic (1.1), France (1.4 ), Germany (1.6). Among the unequivocal institutional obstacles we distinguish: the dependence of the judicial system from other branches of government, low speed of court decisions, low level of trust in the law enforcement system, insufficient degree of execution of court decisions, instability risks, problem of tax evasion, insufficient level fighting the shadow 
economy. Corruption is one of the institutional problems that is an obstacle to financial decentralization in Ukraine. The corruption control index illustrates that Moldova (-1.0), Ukraine (-0.8) and Serbia (-0.3) have the lowest score among the study group. International organizations define the following list of the main problems of Ukraine: the corruption component in the state authorities; misuse of funds from the state (local) budget by authorized officials; corruption payments in the spheres of public services, tax services, judicial system, export-import operations; insufficient degree of combating corrupt manifestations.

One of the most important institutional prerequisites for a financial decentralization reform is the effectiveness of public administration, since even an ideally mapped reform map faces realities at the level of territorial communities. Consequently, the significance of the index of the effectiveness of public administration bodies is analyzed, since it is precisely from the quality of the organization of the provision of public services, the degree of bureaucracy, the qualifications of public service agencies, the level of public confidence in local authorities and the state of implementation of the financial decentralization planned at the state level . We will summarize the importance of the index of efficiency of state administration bodies for the selected group of investigated countries for the period 2006-2016 in Figure 1.

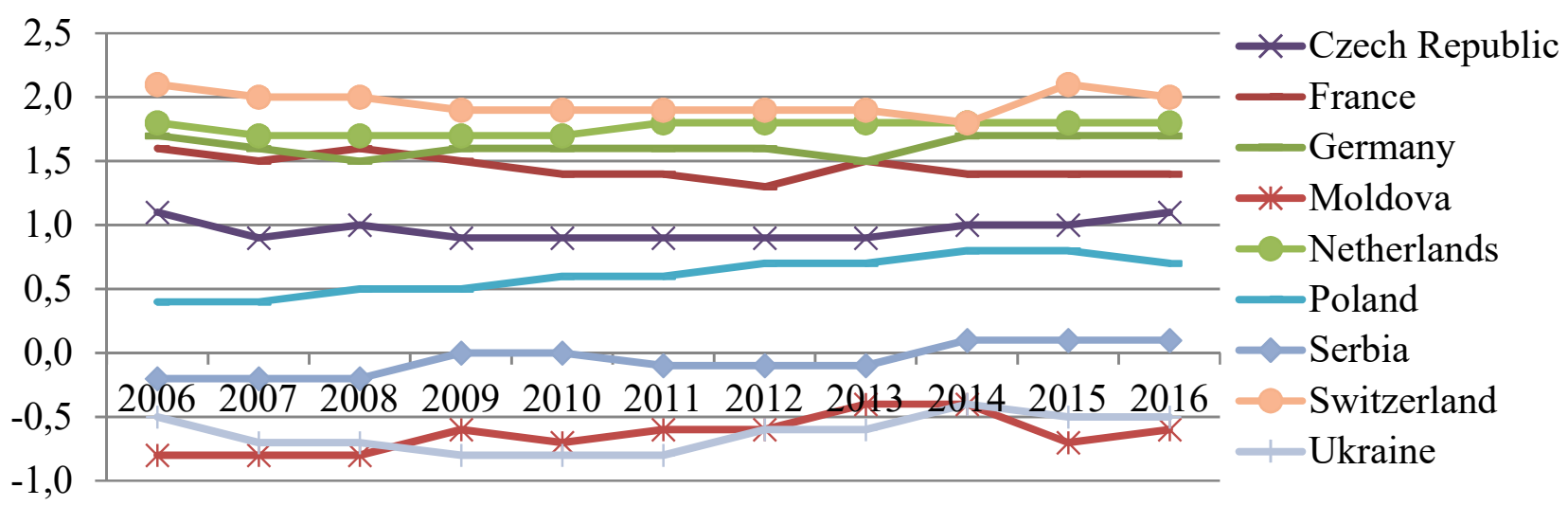

Figure 1. Dynamics of change of the index of efficiency of state administration bodies for 2006-2016 (The Worldwide Governance Introduction)

The results show that Ukraine has made some progress in improving the functioning of state administration, in particular, from 2011 to 2016, the index has increased from -0.8 to -0.5. Compared to neighboring countries, Moldova is estimated to be approximately equal to Ukraine. Significant progress in Poland should be noted, since over the decade the index has increased from 0.4 to 0.7 . Switzerland and the Netherlands remain the leaders in the group during the whole period, with average marks exceeding 1.8 points. The reasons for this include the general institutional effectiveness, that is, the lack of bureaucracy, the high degree of satisfaction of public needs (education, medicine, road infrastructure), the effectiveness of mobilizing revenue sources at different levels of budgets. One of the key factors that needs additional research in our work is the corruption control index. Among the reasons for the urgency of this problem in Ukraine, it is possible to allocate the distribution of many types of corruption schemes at different levels, which leads to the squandering of budget funds. But if we take into account the fact that financial decentralization involves the removal of even more powers and, consequently, of financial resources, the risk of corrupt component increases. We propose to analyze the dynamics of the change of the corruption control index in order to analyze the institutional prerequisites for financial decentralization, as shown in Figure 2.
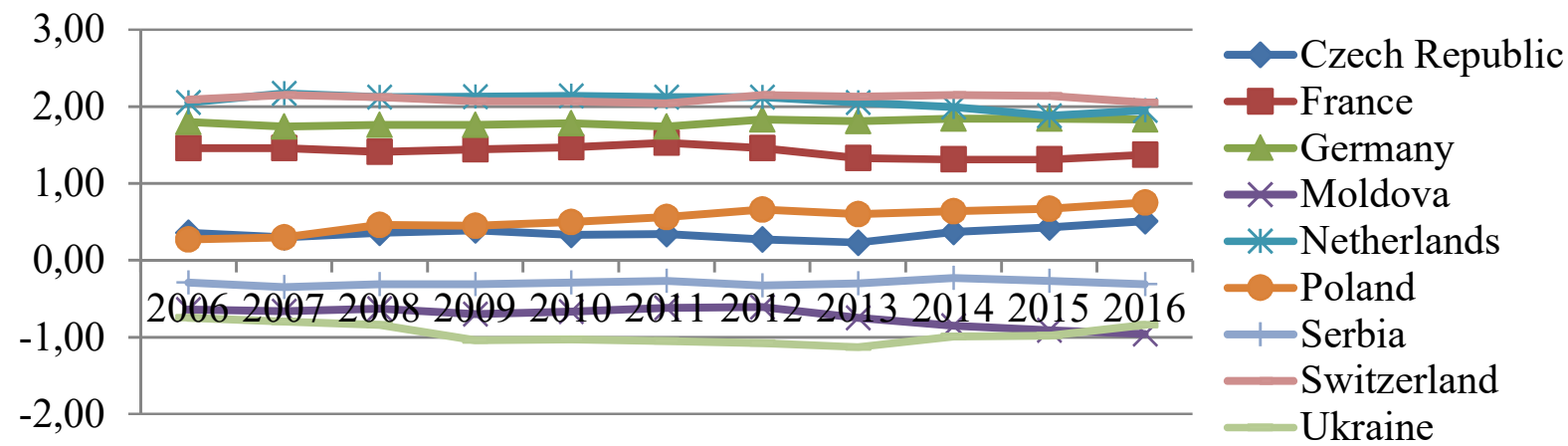

Figure 2. Dynamics of change in the corruption control index for 2006-2016 (The Worldwide Governance Introduction) 
The results of earlier analysis of the corruption index of selected countries for 2016 do not differ significantly from the ten-year period. It should be noted that among the selected group of countries, Ukraine de-monetized the worst estimates of the corruption component, except in 2016, when the domestic result improved from 0.98 to -0.84 points, while Moldova's assessments worsened to -0.96 points. In general, Moldova has recently shown a negative tendency for deterioration of the investigated indicator, in particular, the index value has decreased by 0.21 points over the last 4 years. Switzerland and the Netherlands are leaders in the level of corruption control, which annually demonstrate estimates of more than 2 points out of a possible 2.5 and fall to $10 \%$ of world leaders. Poland is the most dynamically growing country under study, which over the decade has improved its estimates from 0.27 to 0.75 points. Attention should be drawn to the experience of Poland that, through the fight against corruption at various levels (tax abuse, corruption of influential officials, verification of property declarations of public persons, etc.), has become a leader in Eastern Europe. Ukraine has the lowest estimates of the corruption component in 2013 (-1.13), but in the subsequent years the situation has improved. Among the positive factors in changing the Ukrainian corruption realities, international experts highlight: modernization and creation of a legal and regulatory framework for the prevention of corruption, the formation of new anti-corruption bodies (NABU, SAP, Nazok), creation of public mechanisms for openness and transparency of state-sanctioned procedures (Prozorro system, eData, eHealth). Definitely, the domestic tendency to change the situation is better, but it is necessary to continue the chosen policy to fight corruption. We consider it appropriate to continue the study of the corruption component as an institutional link to the path of financial decentralization. One of the most well-known and authoritative indicators of corruption assessment is the Corruption Perceptions Index, which is the product of Transparency International, an international independent organization. This is an aggregate index that provides information on the state of corruption in various sectors of the public sector. This indicator shows the level of perception of corruption by respondents-residents of the country on a steady scale. The rating reflects an estimate from 0 (maximum level of corruption) to 100 (no corruption). We note that the Corruption Perceptions Index is published annually since 1995. Starting from 2012, the calculation methodology implies the possibility of an annual comparison of the country's new indicator with the previous one. Consequently, we compare the results of the assessment of the perception of co-ruption among the selected group of countries for 2012-2016 based on Table 3.

Table 3. Transparency International Corruption Perceptions Index for 2012-2016 (Transparency International's Corruption Perceptions Index)

\begin{tabular}{|l|c|c|c|c|c|}
\hline \multirow{2}{*}{ Country } & \multicolumn{5}{c|}{ Year } \\
\cline { 2 - 6 } & 2012 & 2013 & 2014 & 2015 & 2016 \\
\hline Czech Republic & 49 & 48 & 51 & 66 & 55 \\
\hline France & 71 & 71 & 79 & 81 & 69 \\
\hline Germany & 79 & 78 & 35 & 33 & 81 \\
\hline Moldova & 36 & 35 & 83 & 84 & 30 \\
\hline Netherlands & 84 & 83 & 61 & 63 & 83 \\
\hline Poland & 58 & 60 & 36 & 37 & 62 \\
\hline Serbia & 39 & 42 & 86 & 86 & 40 \\
\hline Switzerland & 86 & 85 & 26 & 27 & 86 \\
\hline Ukraine & 26 & 25 & & 29 \\
\hline
\end{tabular}

As a result of the comparison, it can be said that the lowest level of corruption among selected countries in Switzerland (86), the Netherlands (83) and Germany (81). In fact, the data are comparable to the previously analyzed corruption control index. According to the results of the study, Ukraine did not show values above 29 , which indicates a fairly high level of corruption component. In the total ranking, Ukraine ranked 130th out of 180 countries survey participants. It is possible to highlight the positive practices of countries in the region of Central and Eastern Europe: the Czech Republic and Poland, which are gradually establishing anticorruption and anti-corruption systems. Instead, Moldova shows a worsening of the situation, so from 2012 to 2016, the score fell from 36 to 30 points. Other countries did not demonstrate significant changes in the estimates.

Further analysis of the institutional conditions for financial decentralization has led to the need for an examination of some aspects of economic freedom. In particular, in our study we propose to investigate several factors of budgetary freedom, which depends on the authorities. Each of the indexes of economic freedom (Heritage Foundation's Index of Economic Freedom) is evaluated on a scale according to which qualitative or 
quantitative characteristics are translated into points from 0 to 100: the higher the value of the indicator, the less the state's intervention in the economy and the greater the level economic freedom (Heritage Foundation's Index of Economic Freedom Index).

Table 4. Tax Burden Heritage Foundation's IEF 2012-2016 (Heritage Foundation's Index of Economic Freedom Index)

\begin{tabular}{|l|c|c|c|c|c|}
\hline \multirow{2}{*}{ Country } & \multicolumn{5}{c|}{ Year } \\
\cline { 2 - 6 } & 2012 & 2013 & 2014 & 2015 & 2016 \\
\hline Czech Republic & 82.0 & 82.0 & 81.7 & 81.5 & 82.5 \\
\hline France & 53.8 & 53.0 & 48.4 & 47.5 & 47.7 \\
\hline Germany & 61.3 & 61.8 & 61.2 & 60.8 & 61.5 \\
\hline Moldova & 86.5 & 87.2 & 85.8 & 85.1 & 85.4 \\
\hline Netherlands & 51.2 & 52.1 & 88.0 & 51.8 & 52.7 \\
\hline Poland & 74.4 & 76.0 & 76.1 & 82.1 & 75.5 \\
\hline Serbia & 84.1 & 84.2 & 83.1 & 82.4 & 84.3 \\
\hline Switzerland & 67.9 & 68.1 & 68.9 & 70.3 & 70.9 \\
\hline Ukraine & 78.2 & 78.2 & 79.1 & 78.7 & 78.6 \\
\hline
\end{tabular}

The tax burden index actually indicates the level of fiscal pressure on both personal and corporate income. Accordingly, citizens and business entities have questions regarding the payment, evasion or minimization of taxation. The state and local authorities should be wary of setting different tax rates in order to maintain budget revenues. Consequently, the weighted tax burden is a prerequisite for a successful reform of financial decentralization. It should be noted that, according to Heritage Foundation estimates, the tax burden in France is $45.5 \%$ of GDP, while in Ukraine it is $35.5 \%$. It should be noted that the level of tax burden (economic pressure) in countries with a high level of social standards is quite significant, but the degree of satisfaction of the needs of citizens is at a level. That is, high estimates of the tax burden index are offset by low scores due to insufficient development of other freedoms of citizens (business environment, monetary freedom, etc.).

Table 5. Government Spending Heritage Foundation's IEF for 2012-2016 (Heritage Foundation's Index of Economic Freedom Index)

\begin{tabular}{|l|c|c|c|c|c|}
\hline \multirow{2}{*}{ Country } & \multicolumn{5}{c|}{ Year } \\
\cline { 2 - 6 } & 2012 & 2013 & 2014 & 2015 & 2016 \\
\hline Czech Republic & 36.8 & 43.5 & 43.8 & 40.6 & 47.3 \\
\hline France & 5.3 & 5.6 & 5.6 & 2.5 & 2.5 \\
\hline Germany & 32.2 & 37.3 & 38.2 & 40.1 & 41.3 \\
\hline Moldova & 38.7 & 50.1 & 54.4 & 51.8 & 55.6 \\
\hline Netherlands & 20.9 & 24.7 & 51.7 & 23.8 & 34.4 \\
\hline Poland & 40.3 & 43.0 & 43.2 & 47.1 & 46.5 \\
\hline Serbia & 39.3 & 40.3 & 38.6 & 27.1 & 44.1 \\
\hline Switzerland & 65.8 & 63.8 & 65.7 & 65.1 & 66.3 \\
\hline Ukraine & 29.4 & 29.4 & 37.5 & 28.0 & 30.6 \\
\hline
\end{tabular}

The optimal level of public spending is also an institutional prerequisite for successful financial decentralization. The ideal level of public spending in relation to GDP will vary depending on various factors of economic development. It is necessary to take into account the fact that at one time the amount of public expenditures may exceed the actual budget capacity to compensate for this amount, which will result in inefficient use of financial resources and loss of economic efficiency. Excessive government spending leads to a deficit and the appearance of public debt. It should be noted that according to the methodology for calculating this index, economically weak countries can obtain higher scores of economic freedom than those that are more advanced, but under other components of economic freedom they receive lower marks (financial freedom, freedom of investment). The low estimates of France are explained by the fact that expenditures are close to the limit set by experts at $57 \%$, the budget deficit also exceeds the established framework $(3.6 \%$ of GDP), and the state debt is $96.6 \%$ of GDP. Indicators of Ukraine are estimated at a satisfactory level, but the indicators of budget deficit and public debt in the future will be a factor in reducing existing estimates. The best way to summarize the analysis of each of the investigated quantitative indicators of the institutional environment for conducting a reform of financial decentralization is to create an integral indicator. The appropriateness of constructing an integral indicator is due to the fact that the number of analyzed indicators is significant, they are heterogeneous in nature, it is impossible to distinguish the most significant of them. The algorithm for constructing our integral indicator pre-sees a few steps. The formed set of output indices with the group of studied countries was normalized to bring to a uniform comparative form. The most appropriate in our case was the absolute normalization. The next step was to use the method of additive 
convolution of the criteria, since each of the selected factors addictively and linearly affects the creation of institutional conditions for financial decentralization. The results are grouped in the form of Table 6 .

Table 6. Index of institutional conditions for financial decentralization for 2012-2016

\begin{tabular}{|l|c|c|c|c|c|}
\hline \multirow{2}{*}{ Country } & \multicolumn{5}{c|}{ Year } \\
\cline { 2 - 6 } & 2012 & 2013 & 2014 & 2015 & 2016 \\
\hline Czech Republic & 5.7 & 5.9 & 5.9 & 6.0 & 6.1 \\
\hline France & 5.2 & 5.3 & 5.2 & 5.1 & 5.0 \\
\hline Germany & 6.7 & 7.0 & 7.3 & 7.3 & 7.2 \\
\hline Moldova & 2.5 & 3.0 & 3.0 & 2.8 & 2.6 \\
\hline Netherlands & 7.1 & 7.1 & 8.5 & 7.1 & 7.3 \\
\hline Poland & 5.6 & 5.7 & 5.8 & 6.1 & 5.5 \\
\hline Serbia & 2.8 & 3.3 & 3.4 & 3.4 & 3.5 \\
\hline Switzerland & 8.4 & 8.4 & 8.5 & 8.6 & 8.6 \\
\hline Ukraine & 1.2 & 1.2 & 1.3 & 1.3 & 1.3 \\
\hline
\end{tabular}

The index we created was called the Index of institutional conditions for financial decentralization. He summarizes the state of the internal environment, which in a complex characterizes the effectiveness of the reform of financial decentralization. The results confirm previously made conclusions on the individual components of the index. The greater the value of the resulting integral indicator, the better is the financial decentralization in the country, as all the conditions for this exist. Among the study group of countries Ukraine is in the last place. This is characterized by the fact that it is necessary to solve a number of obstacles to successful reform. It should be borne in mind that some countries in the selected group have decades of experience in gradually adjusting the institutional environment. In order to increase its own rating, Ukraine first of all should concentrate on solving the issues of political stability, ensuring a safe environment within the country, increasing the efficiency of public authorities, overcoming corruption and the like. Definitely should take a positive experience of leading countries: Switzerland, the Netherlands, Germany.

\section{Conclusions}

Consequently, the state of the institutional environment directly affects the effectiveness of the reform of financial decentralization. Having carried out a general analysis of the institutional conditions of an effective reform of financial decentralization, the following problematic aspects are required: insufficient level of accountability of state authorities, insufficient level of observance of civil rights, low level of trust in existing power, ineffective activity of state administration bodies. Particular attention was paid to the corruption component of the institutional environment, and analyzed the Transparency International Corruption Perceptions Index (The Worldwide Governance Indicators) and the Corruption Perceptions Index (Corruption Perceptions Index). The construction of the integral index of institutional conditions for financial decentralization allowed us to summarize the study of heterogeneous indicators, which resulted in a general and complete picture of the institutional environment in the countries under study.

\section{References}

1. Akudugu, JA. (2018). Institutionalizing local economic development practice in Ghana. Local economy. Volume 33, Issue 4, 405-420. doi: 10.1177/0269094218774250.

2. Andriyash, V. I. (2014) Institutsionalizatsiya: ponyatie i soderzhanie. Sovremennyie nauchnyie issledovaniya i innovatsii [Institutionalization: Concept and Content. Modern scientific research and innovation], 11. Available at: http://web.snauka.ru/issues/2014/11/39534.

3. Aoki, M. (2007). Endogenizing Institutions and Institutional Changes. Journal of Institutional Economics, Volume 3, Issue 1, 1-31.

4. Bakir, C., Jarvis, D. S. L. (2018). Institutional and Policy Change: Meta-theory and Method Studies in the Political Economy of Public Policy, 1-38. doi: 10.1007/978-3-319-70350-3_1.

5. Bathelt, H., Glueckler, J. (2014). Institutional change in economic geography. Progress in human geography, Vol. 38, No. 3, 340-363. doi: 10.1177/0309132513507823.

6. Campbell, J. Institutional change and globalization. (2004). Princeton University Press. 247 p.

7. Cherkasov, O. M., Radchenko, O. V. (2007). Detsentralizatsiya vladi: polski uroki dlya Ukrayini. Derzhavne budivnitstvo [Decentralization of power: Polish lessons for Ukraine. State building], 1(2), $11 \mathrm{p}$. Available at: http://www.kbuapa.kharkov.ua/e-book/db/2007-1-2/doc/5/03.pdf.

8. Cushinskiy, O. I. (2002). Kontrol u sferi publichnoyi vladi: teoretiko-metodologichni ta organizatsiyno- 
pravovi aspekti. Lviv: LIDUUADU [Control in the field of public authority: theoretical-methodological and organizational-legal aspects]. Lviv: LIDUUAD, $375 \mathrm{p}$.

9. Dudchenko, V., Vitman, K. (2018). Public administration of economic development in the context of the institutional theory. Baltic journal of economic studies, 4(1), 139-147. doi: 10.30525/2256-0742/2018-1-1139-147.

10. Gooneratne, T. N., Hoque, Z. (2016). Institutions, agency and the institutionalization of budgetary control in a hybrid state-owned entity. Critical perspectives on accounting, Volume 36, 58-70. doi: 10.1016/j.cpa.2015.12.003.

11. Heritage Foundation's Index of Economic Freedom Index. Available at: https://www.heritage.org/index/. 12. Infrastrukturne zabezpechennya Institutsiynoyi stiykosti sotsialno-ekonomichnoyi sistemi region. Available at: http://ekon.in.ua/infrastrukturne-zabezpechennya-institucijnoyi-stijkosti-social-v3.html.

13. Inshakov, O. V. (2005). Homo institutius - Chelovek institutsionalnyiy: monograflya pod red. O. V. Inshakova. Volgograd: VolGU. 620 p.

14. Kingston, C., Caballero, G. (2009). Comparing theories of institutional change. Journal of Institutional Economics, 5(2), 151-180. doi: 10.1017/S1744137409001283.

15. Kolodiy, A. F. (2002). Osnovi demokratiyi. Ministerstvo osviti i nauki Ukrayini. Institut vischoyi osviti APN Ukraiini. Ukrayinsko-kanadskiy proekt "Demokratichna osvita". [The basis of democracy. Ministry of Education and Science of Ukraine. Institute of Higher Education of the APN Ukraine. Ukrainian Canadian project "Democratic Education"], 684 p.

16. Kravchenko, S. Modelyuvannya mehanizmu zdiysnennya derzhavno-upravlinskih reform. (2009). Visnik Natsionalnoyi akademiyi derzhavnogo upravlinnya. [Modeling the mechanism of implementation of statemanagement reforms. (2009). Bulletin of the National Academy of Public Administration], №2. Available at: http://visnyk.academy.gov.ua/wp-content/uploads/2013/11/2009-2-12.pdf.

17. Kuhta, B., Romanyuk, A., Staretska, L. (2003). Politichna nauka. Slovnik: kategoriyi, ponyattya i termini. Kalvariya. [Political Science. Dictionary: categories, concepts and terms. Calvaria]. 172 p.

18. Lazor, O. D. (2009). Institutsionalizatsiya publichnoyi samovryadnoyi vladi v Ukrayini. Lviv. [Institutionalization of public self-government in Ukraine]. LIDU NADU, $56 \mathrm{p}$.

19. Milbradt, G. (2015). Detsentralizatsiya: gde mozhno, a gde nelzya?. [ Decentralization: where is it possible, and where is it not possible? ]. Available at: http://politcom.org.ua/?p=10350.

20. North, D. (1981). Structure and Change in Economic History. New York, W.W. Norton \& Co.

21. Osipova, N. P. (2003). Ponyattya i oznaki sotsialnogo Institutu. Mehanizmi zdiysnennya Institutsionalizatsiyi. YurInkomInter. [Concepts and features of the Social Institute. The Mechanism of Implementation of the Institute for Social Development. Yurinkom-Inter]. 67 p.

22. Soukopova, J., Bakos, E., Zelenakova, P. (2017). Institutional and Managerial Aspects of Intermunicipal Cooperation. Proceedings of the 21st international conference current trends in public sector research, 379386.

23. Strategiya reformi publichnoyi administratsiyi v Respublitsi Serbiya. [The strategy of public administration reform in the Republic of Serbia.] (2004). Belgrad: Uryad Respubliki Serbiya, 58 p. Available at: http://www.pravo.org.ua/?w=r\&i=\&d=486.

24. Swenden, W. (2017). Governing Diversity in South Asia: Explaining Divergent Pathways in India and Pakistan. The Journal of Federalism, Volume 48, Issue 1, 102-133.

25. The Worldwide Governance Indicators (WGI) project. Available at: http://info.worldbank.org/governance/wgi/\#home.

26. The Worldwide Governance Introduction. Available at: http://info.worldbank.org/governance/wgi/\#docintro.

27. Thomsen, J., (2008). Processes of localization and institutionalization of local managers in economic functions in danish owned subsidiaries in estonia, latvia and lithuania around the 21st century. Proceedings Paper 5th International Scientific Conference on Business and Management, 91-98.

28. Transparency International's Corruption Perceptions Index. Available at:https://www.transparency.org/news/feature/corruption_perceptions_index_2017.

29. Zelenko, G. I. (2010). Institutsionalizatsiya gromadyanskogo suspilstva u postsotsalistichnih krayinah (na prikladi krayin Vishegradskoyi grupi ta Ukrayini. [Institute for strengthening civic support in the post-soviet countries (on the example of the edge of the Visegrad Group of Ukraine], $36 \mathrm{p}$. 